\title{
Study for Improving an Duong Lake Water Quality for Chi Lang Nam Stork Island Conservation and Ecotourism Development
}

\author{
${ }^{1}$ Tran Yem, ${ }^{2}$ Nguyen Xuan Hai, ${ }^{1}$ Nguyen Manh Khai and ${ }^{3}$ Nguyen Xuan Huan \\ ${ }^{1}$ Department of Environmental Technology, Faculty of Environmental Sciences, VNU University of Science (HUS), Hanoi \\ ${ }^{2}$ Department of Pedology and Soil Environment, Faculty of Environmental Sciences, VNU University of Science (HUS), Hanoi \\ ${ }^{3}$ Laboratory for Environmental Analysis, Faculty of Environmental Sciences, VNU University of Science (HUS), Hanoi
}

Received 2012-09-23, Revised 2013-01-06; Accepted 2013-06-10

\begin{abstract}
An Duong Lake has been selected for the study to its important role in storks' and cauldrons' habitat protection, fishery and ecotourism of Hai Duong Province and particularly Thanh Mien District. Qualitative and quantitative methods were used throughout the research. The overall purpose of this study is to find out some mitigating measures for improving water quality of An Duong Lake in order to conserve herein stork islands and ecotourism development. Specifically, the objectives of the study are included: (i) To identify An Duong Lake pollution sources; (ii) To assess An Duong Lake water quality; (iii) To suggest water pollution mitigating measures. The main sources of water pollution of An Duong Lake are: storks' and cauldrons' feces, domestic and livestock waste and run-off. Wastes of all these sources are discharged directly into the lake without any treatment. In dry and wet season, concentration of SS, BOD and COD of almost samples is higher than regulatory levels (Vietnam National Technical Regulation 08:2008/BTNMT, Class A2 and B1). $\mathrm{pH}$ of all water samples in the range of permissible level. Concentration of $\mathrm{N}^{-\mathrm{NH}_{4}}{ }^{+}$and $\mathrm{N}-\mathrm{NO}_{3}{ }^{-}$is lower than permissible level. The pollution of An Duong Lake water is heavier in dry season than in wet season. Lakeshore water is more contaminated than the central part of lake. Several comprehensive methods for improving An Duong Lake water quality should be conducted such as Water hyacinth (Eichhornia crassipes) and Reed (Phragmites communis) growing for water pollutant mitigation, Septic tank toilet for treatment of domestic waste water; Treatment of livestock wastes; Combination of filtration with EM for mitigating pollutant in run-off; Fish farming; Pollution sources control and An Duong Lake water monitoring. Water hyacinth and reed growing is found out to be the most effective and practical method for mitigating An Duong Lake water contaminants.
\end{abstract}

Keywords: An Duong Lake, Water Pollution, Water Quality, Stork, Cauldron, Mitigation Measure

\section{INTRODUCTION}

An Duong Lake with the area of 90 hectares and the average depth of $8 \mathrm{~m}$ is located in Chi Lang Nam Commune, Thanh Mien District, Hai Duong Province. It connects with Cuuan River and Trieu Duong Lake. There exist two islands inside the lake with the area of 2.500 and 3.000 square meters, respectively. These islands are considered as the habitat of approximately 18.000 storks and cauldrons (Yem, 2012). Therefore, this place is named as Chi Lang Nam Stork Colony which becomes a very famous stork and cauldron conserving place in the north of Vietnam. This stork island attracts thousands of people visiting annually. Chi Lang Nam Stork Island turns out to be one of most noticeable tourism destinations and historical relic of Hai Duong Province, Viet Nam.

In fact, An Duong Lake now is contaminated by storks' and cauldrons' feces, domestic waste water, livestock waste water, run-off from rice fields and solid

Corresponding Author: Tran Yem, Faculty of Environmental Sciences, VNU University of Science (HUS),

Vietnam National University, Hanoi (VNU); tyem48@gmail.com 
waste dumping. Bad smell from storks' feces and dirty water has caused nuisance to visitors and people living in surrounding areas (Yem et al., 2012).

The overall purpose of this study is to find out some mitigating measures for improving An Duong Lake water quality in order to conserve herein stork island and ecotourism development. The specific purpose of this study is to: (i) Identify An Duong Lake pollution sources; (ii) Assess An Duong Lake water quality; (iii) Suggest water pollution mitigation measures.

\section{MATERIALS AND METHODS}

\subsection{Methods}

\subsection{Field Survey}

Water sampling site selections: 12 water sampling sites in An Duong Lake are selected (Table 1 and Fig. 1):

\subsection{Measurement}

Use portable instruments for measurement of some parameters like: $\mathrm{pH}, \mathrm{DO} \ldots$ The instrument model U-10 Horiba-Japan was used.

Water pollution source survey.

\subsection{PRA}

- Organizing a meeting with 40 farmers of An Duong Village

- Interview:

- Chairman and two officers of Chi Lang Nam People Committee

- Mr. Ban-Chief of Management Board of Stork Island

- Mr. Dao Quang Canh-74 years old, An Duong Villager

\subsection{Laboratory Analysis}

Chemical analyses were conducted in the environmental analysis laboratory of faculty of environmental sciences, VNU University of Science (HUS), belonging to Vietnam National University, Hanoi (VNU).

\subsection{Experiment}

\subsection{Stimulation Filtration Trench}

- 3-compartments horizonetal filter with each apartment dimension of $50 \times 30 \times 30 \mathrm{~cm}$

- Gravels with diameter of 2-2.5 cm, coarse sands

- Use 100, 200, 300gr of storks' feces diluted in 101 of wells water

Figure 2 present the experiment of stimulation filtration trench

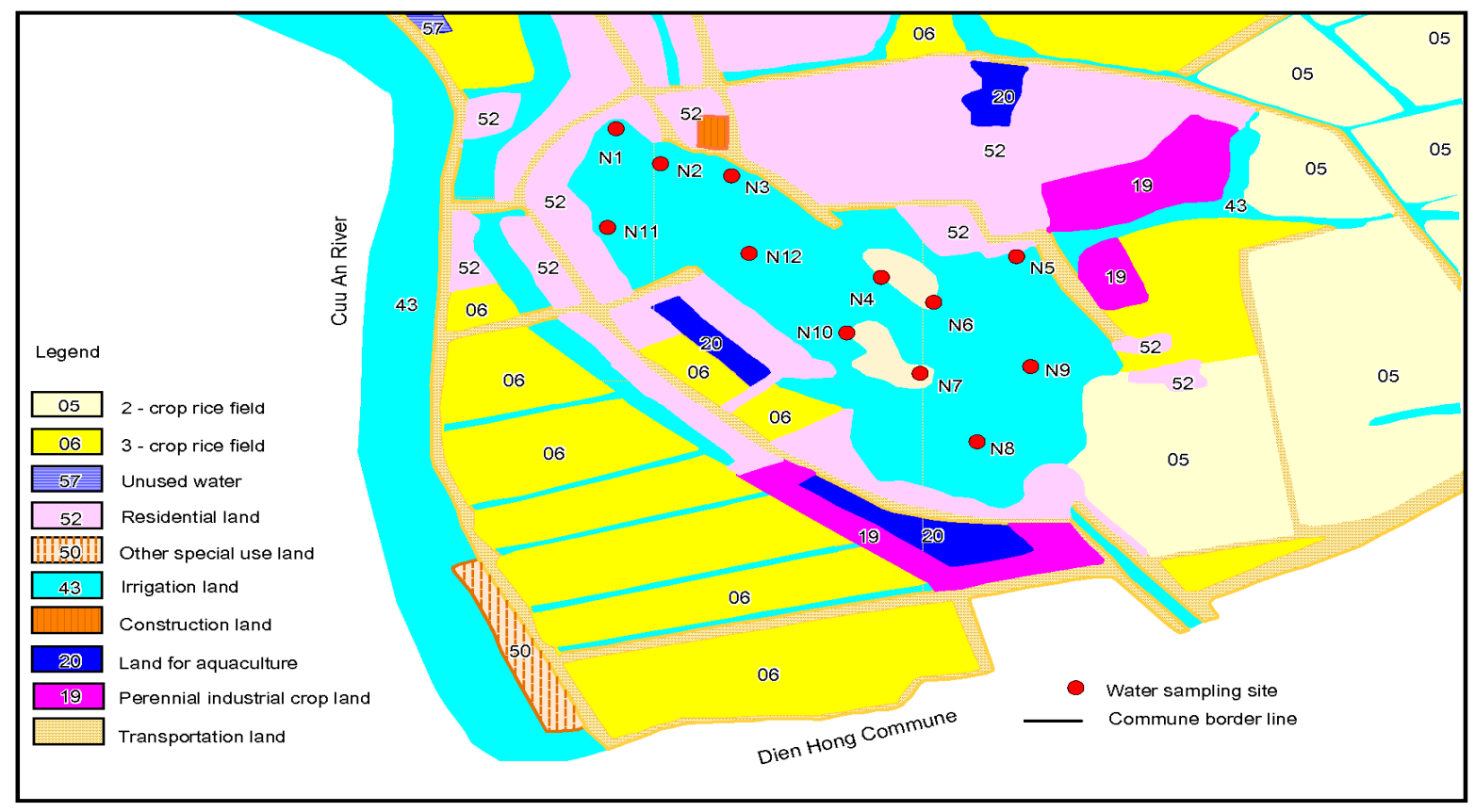

Fig. 1. Water sampling sites 
Table 1. Water sampling site description

\begin{tabular}{|c|c|c|c|}
\hline $\begin{array}{l}\text { Sampling } \\
\text { site no. }\end{array}$ & Sampling site & $\begin{array}{l}\text { Geographic } \\
\text { coordinates }\end{array}$ & Description \\
\hline N1 & At inlet-WEST North of the Lake & E: $105^{\circ} 43^{\prime} 27,3^{\prime \prime} \mathrm{N}: 20^{\circ} 43^{\prime} 24,5^{\prime \prime}$ & Households near inlet \\
\hline N2 & Close to floating restaurant & E: $105^{\circ} 43^{\prime} 28,4^{\prime \prime} \mathrm{N}: 20^{\circ} 43^{\prime} 23,8^{\prime \prime}$ & \\
\hline N3 & At the marina & E: $105^{\circ} 43^{\prime} 29,9^{\prime \prime} \mathrm{N}: 20^{\circ} 43^{\prime} 23,5^{\prime \prime}$ & There are some small shop at the shore \\
\hline N4 & At the Western part of the New Island & $: 105^{\circ} 43^{\prime} 34,1^{\prime \prime} \mathrm{N}: 20^{\circ} 43^{\prime} 18,9^{\prime \prime}$ & $1.5 \mathrm{~m}$ from shoreline, in the hyacinth plot (piece) \\
\hline N5 & At the North East drainage gate & E: $105^{\circ} 43^{\prime} 38,6^{\prime \prime} \mathrm{N}: 20^{\circ} 43^{\prime} 19,9^{\prime \prime}$ & $\begin{array}{l}\text { Close to Dong Trau rice field, households at the } \\
\text { left site of the drainage gate }\end{array}$ \\
\hline N6 & At the South East part of the New Island & E: $105^{\circ} 43^{\prime} 35,9^{\prime \prime} \mathrm{N}: 20^{\circ} 43^{\prime} 17,7^{\prime \prime}$ & $3 \mathrm{~m}$ from shoreline, out of hyacinth plot \\
\hline N7 & At the South East part of the Old Island & E: $105^{\circ} 43^{\prime} 35,3^{\prime \prime} \mathrm{N}: 20^{\circ} 43^{\prime} 15,7^{\prime \prime}$ & The water area between two island, no hyacinth \\
\hline N8 & At the South East $p$ & $105^{\circ} 43^{\prime} 38,7^{\prime \prime} \mathrm{N}: 20^{\circ} 43^{\prime} 11,6^{\prime \prime}$ & $10 \mathrm{~m}$ from North East outlet (drainage gate) \\
\hline N9 & At the fishing tent in the South East part of the lake & E: $105^{\circ} 43^{\prime} 38,3^{\prime \prime} \mathrm{N}: 20^{\circ} 43^{\prime} 15,3^{\prime \prime}$ & $15 \mathrm{~m}$ from shoreline of New Island \\
\hline N10 & At the North West part of the OLD Island & E: $105^{\circ} 43^{\prime} 33,1^{\prime \prime} \mathrm{N}: 20^{\circ} 43^{\prime} 17,1^{\prime \prime}$ & $1.5 \mathrm{~m}$ from shoreline, no hyacinth \\
\hline N11 & At the North West part of the lake & E: $105^{\circ} 43^{\prime} 26,6^{\prime \prime} \mathrm{N}: 20^{\circ} 43^{\prime} 21,3^{\prime \prime}$ & $\begin{array}{l}2 \mathrm{~m} \text { from shoreline, on the lakeshore, } \\
\text { there are some households }\end{array}$ \\
\hline N12 & At the centre of North West part of the lake & E: $105^{\circ} 43^{\prime} 30,2^{\prime \prime} \mathrm{N}: 20^{\circ} 43^{\prime} 20,5^{\prime \prime}$ & $30 \mathrm{~m}$ from the Old Island \\
\hline
\end{tabular}
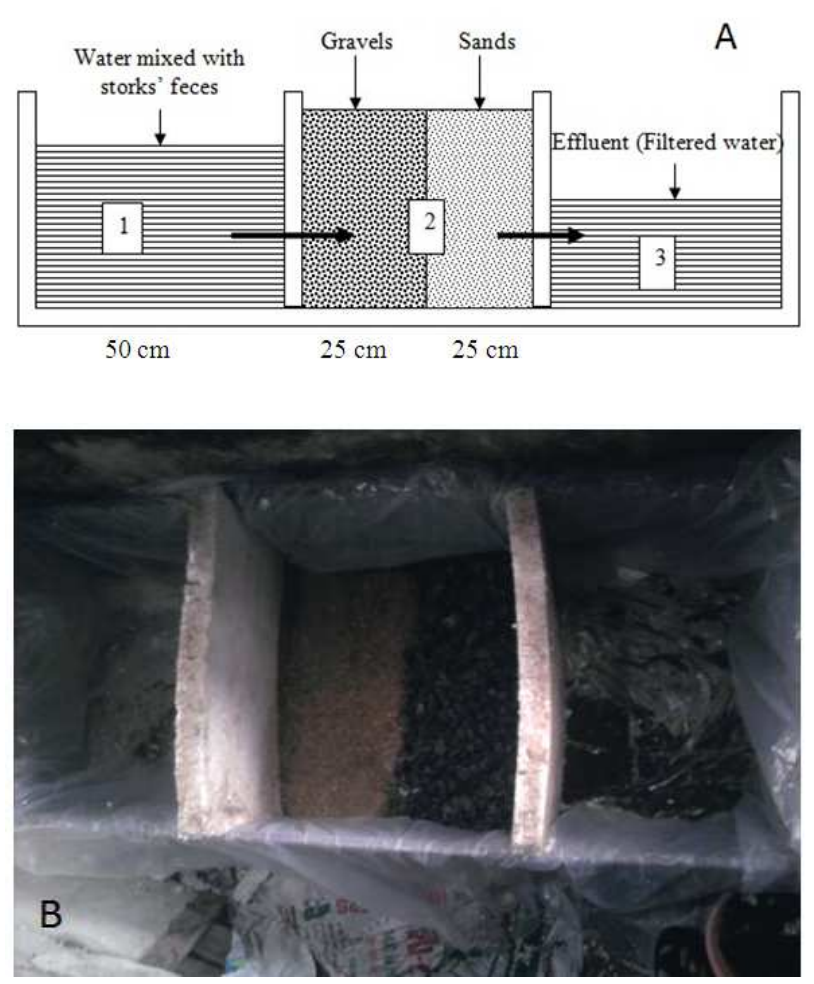

Fig. 2. (A and B): Experimental pattern of horizonetal filter

\subsection{Experement with Hyacinth}

- 3 separate foam boxes are used for experiment. Dimension of each box is $65 \times 40 \times 30 \mathrm{~cm}$

- Water is taken from An Duong Lake

- Hyacinths with heighth (root + leaf) of $15-20 \mathrm{~cm}$.

- Hyacinths cover in: Box 1: $100 \%$ surface area of box; Box 2: 50\% surface area of box; Box 3: $30 \%$ surface area of box

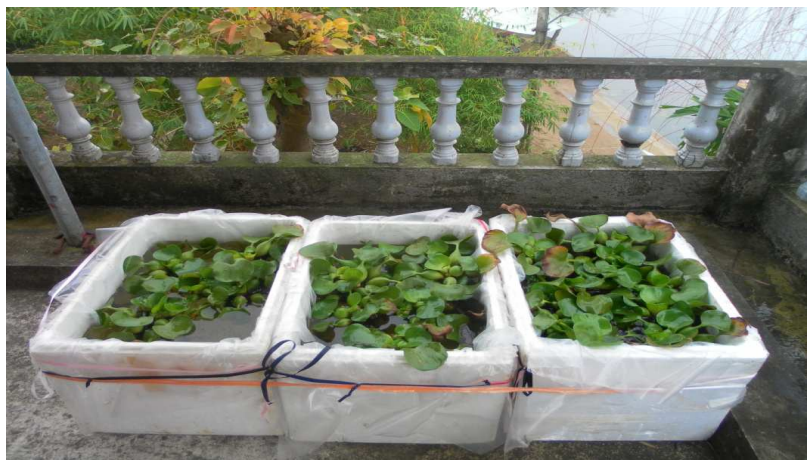

Fig. 3. Water treatment experimental pattern by hyacinths

Figure 3 present the experiment of water treated by hyacinth.

\subsection{Tools}

- Intruments for water sampling: DR 2010 (USA), Plastic bottle and container

- GPS, Portable instruments for water measurement (TOA Model U-10 Horiba-Japan)

- Maps

- Questionaire

\section{RESULTS AND DISCUSSION}

\subsection{An Duong Lake Water Quality}

\subsubsection{Water Pollution Sources}

The main sources causing the degradation of An Duong Lake water quality:

- Storks' and cauldrons' feces: It is estimated that about $500 \mathrm{~kg}$ of storks' and cauldrons' feces produced per day. A large part of feces are 
absorbed by the soil layers of the islands. The smaller amount of feces runs directly into lakeshore water (the water area surrounding islands). In rainy days, run-off from islands brings storks' and cauldrons' feces into the lake and cause pollution for the lake

- Domestic waste water: Everyday, about 140$150 \mathrm{~m}^{3}$ of domestic waste water are discharged into An Duong Lake. This waste water come from households of An Duong Village in which 50 households are located on the lakeshore. Based on loading coefficient of domestic waste water (Table 2) provided by WHO, 1993, everyday, An Duong Lake may receive $75 \mathrm{~kg} \mathrm{BOD}_{5}, 130 \mathrm{~kg}$ COD, $150 \mathrm{~kg} \mathrm{SS}, 13.5 \mathrm{~kg} \mathrm{~N}, 5 \mathrm{~kg}$ Ammonia and $3.5 \mathrm{~kg} \mathrm{P}_{\text {total }}$

- Livestock waste water: There have been about 50 households around the lake having pig farms. Everyday, these households may discharge into An Duong Lake about 4-5 $\mathrm{m}^{3}$ of waste water. Base on the guideline of JSWA (1997) on Sewage planning for watershed, pollutant loading of pig farming discharged into An Duong Lake is estimated: $10 \mathrm{~kg}$ of $\mathrm{BOD}_{5}, 35 \mathrm{~kg}$ of $\mathrm{SS}, 2 \mathrm{~kg}$ of $\mathrm{N}_{\text {total }}$ and $1 \mathrm{~kg}$ of $\mathrm{P}_{\text {total }}$
- Run-off: heavy rains (about $100 \mathrm{~mL} /$ day) may cause run-off in this area. It is estimated $1.800 \mathrm{~m}^{3}$ run-off of one heavy rain being discharged into An Duong Lake (300ha $\times 100 \mathrm{~mL}^{-1} \times 60 \%$ of rain fall). Pollutant loading from run-off is calculated: $36 \mathrm{~kg}$ of $\mathrm{BOD}_{5}, 4$ $500 \mathrm{~kg}$ of $\mathrm{SS}, 57 \mathrm{~kg}$ of $\mathrm{N}_{\text {total }}$ and $0.6 \mathrm{~kg}$ of $\mathrm{P}_{\text {total }}$

\subsubsection{Water Quality}

\subsubsection{Dry Season (From December to April Next year)}

In comparison with Vietnam National Technical Regulation 08:2008/BTNMT, in dry seasons, concentration of SS of Samples N2, N4, N5 is lower than $\mathrm{B} 1$ class, $\mathrm{BOD}_{5}$ of $\mathrm{N} 8$ is lower than the Permissible level (B1 class). Concentration of COD of water samples $\mathrm{N} 8, \mathrm{~N} 12$ is lower than B1 class. $\mathrm{pH}$ of all samples is nearly the same as $\mathrm{pH}$ Permissible level (Table 3).

Concentration of $\mathrm{N}-\mathrm{NH}_{4}{ }^{+}$and $\mathrm{N}_{-} \mathrm{NO}_{3}{ }^{-}$is lower than Permissible level (both A2 and B1 class).

Analysis from Table 4 and Fig. 1 shows that quality of water area close to islands and residents (sample No. $\mathrm{N} 1, \mathrm{~N} 6, \mathrm{~N} 7, \mathrm{~N} 11$ ) is lower than quality of water area which is far from islands and lakeshore line and covered by hyacinths (N4, N5, N12).

Table 2. Characteristics of An Duong lake water in dry season and wet season

\begin{tabular}{|c|c|c|c|c|c|c|c|c|c|c|c|c|c|c|}
\hline \multirow{2}{*}{$\begin{array}{l}\text { Samples } \\
\text { parameters }\end{array}$} & \multirow[b]{2}{*}{ N1 } & \multirow[b]{2}{*}{$\mathrm{N} 2$} & \multirow[b]{2}{*}{ N3 } & \multirow[b]{2}{*}{ N4 } & \multirow[b]{2}{*}{ N5 } & \multirow[b]{2}{*}{ N6 } & \multirow[b]{2}{*}{ N7 } & \multirow[b]{2}{*}{ N8 } & \multirow[b]{2}{*}{ N9 } & \multirow[b]{2}{*}{ N10 } & \multirow[b]{2}{*}{ N11 } & \multirow[b]{2}{*}{ N12 } & \multicolumn{2}{|c|}{ QCVN 08} \\
\hline & & & & & & & & & & & & & $\mathrm{A} 2$ & B1 \\
\hline \multicolumn{15}{|l|}{ Dry season } \\
\hline SS & 60.000 & 50.000 & 55.000 & 48.500 & 45.600 & 65.000 & 64.300 & 60.900 & 62.000 & 59.000 & 53.000 & 54.000 & 30 & 50 \\
\hline $\mathrm{BOD}_{5}$ & 31.000 & 29.000 & 30.000 & 21.000 & 42.000 & 25.000 & 24.000 & 11.000 & 34.000 & 35.000 & 39.000 & 15.000 & 615 & \\
\hline COD & 48.000 & 44.000 & 43.000 & 35.000 & 62.000 & 35.000 & 35.000 & 16.000 & 48.000 & 50.000 & 57.000 & 28.000 & 15 & 30 \\
\hline $\mathrm{pH}$ & 7.070 & 7.210 & 6.890 & 6.970 & 6.840 & 7.150 & 7.230 & 7.190 & 7.010 & 6.640 & 6.870 & 6.970 & $6-8.5$ & $5.5-9$ \\
\hline $\mathrm{P}_{\text {total }}$ & 2.340 & 2.280 & 2.430 & 1.920 & 2.170 & 2.460 & 2.810 & 2.520 & 2.760 & 2.020 & 2.100 & 2.150 & & \\
\hline $\mathrm{N}_{\text {total }}$ & 5.460 & 5.330 & 5.550 & 4.910 & 4.200 & 6.150 & 6.500 & 5.760 & 6.000 & 5.060 & 5.130 & 4.640 & & \\
\hline $\mathrm{N}-\mathrm{NH}_{4}{ }^{+}$ & 0.015 & 0.016 & 0.017 & 0.012 & 0.013 & 0.018 & 0.020 & 0.019 & 0.018 & 0.012 & 0.013 & 0.016 & 0.2 & 0.5 \\
\hline $\mathrm{N}^{-\mathrm{NO}_{3}}{ }^{-}$ & 3.280 & 3.340 & 3.150 & 2.170 & 2.080 & 3.560 & 3.730 & 3.960 & 3.630 & 2.320 & 2.200 & 2.250 & 510 & \\
\hline \multicolumn{15}{|l|}{ Dry season } \\
\hline $\mathrm{SS}$ & 51.600 & 48.000 & 50.000 & 44.300 & 42.000 & 59.000 & 60.500 & 57.800 & & & & 51.000 & 30 & 50 \\
\hline $\mathrm{BOD}_{5}$ & 27.000 & 26.000 & 28.000 & 20.000 & 35.000 & 18.000 & 18.000 & 7.000 & 27.000 & 30.000 & 33.000 & 10.000 & 615 & \\
\hline COD & 41.000 & 38.000 & 41.000 & 29.000 & 51.000 & 26.000 & 25.000 & 13.000 & 38.000 & 45.000 & 54.000 & 16.000 & 15 & 30 \\
\hline $\mathrm{pH}$ & 7.150 & 7.220 & 6.910 & 6.930 & 6.940 & 7.100 & 7.090 & 7.110 & 7.060 & 6.990 & 7.020 & 6.850 & $6-8.5$ & $5.5-9$ \\
\hline $\mathrm{P}_{\text {total }}$ & 2.040 & 2.190 & 2.220 & 1.900 & 1.960 & 2.230 & 2.450 & 2.610 & 2.580 & 1.700 & 2.010 & 1.890 & & \\
\hline $\mathrm{N}_{\text {total }}$ & 5.000 & 5.110 & 5.230 & 4.870 & 4.000 & 5.920 & 5.900 & 5.220 & 5.460 & 4.720 & 4.100 & 4.960 & & \\
\hline $\mathrm{N}-\mathrm{NH}_{4}{ }^{+}$ & 0.014 & 0.015 & 0.015 & 0.010 & 0.011 & 0.016 & 0.018 & 0.017 & 0.016 & 0.010 & 0.012 & 0.014 & 0.2 & 0.5 \\
\hline $\mathrm{N}-\mathrm{NO}_{3}^{-}$ & 3.200 & 3.120 & 2.950 & 2.110 & 2.290 & 3.420 & 3.330 & 3.260 & 3.250 & 5.200 & 1.960 & 3.160 & 510 & \\
\hline
\end{tabular}

Note: The classification of surface water to assess water quality and control, for purposes of water use vary; A1-Good use for water supply purposes and other purposes, such as type A2, B1 and B2; A2-For the purpose of water supply but to apply the appropriate; treatment technology; preservation of aquatic plants, or other purposes, such as type B1 and B2; B1-For irrigation purposes or other purposes required or similar water quality purposes as type B2 use; B2-Transport water and other purposes with low quality water requirements. 
Table 3. Result of experiment of use hyacinth for water pollutant mitigation

\begin{tabular}{|c|c|c|c|c|c|}
\hline \multirow{2}{*}{$\begin{array}{l}\text { No. } \\
\text { Parameters }\end{array}$} & \multicolumn{3}{|c|}{$\begin{array}{l}\text { Experimental } \\
\text { result }(\mathrm{mg} / \mathrm{L})\end{array}$} & \multicolumn{2}{|c|}{$\begin{array}{l}\text { Treatment } \\
\text { efficiency }(\%)\end{array}$} \\
\hline & M0 & M1 & M2 & M1 & M2 \\
\hline $\begin{array}{ll}1 & \mathrm{pH}\end{array}$ & 7.73 & 7.700 & 7.680 & - & - \\
\hline $\mathrm{BOD}_{5}$ & 38.40 & 5.720 & 18.740 & 85.1 & 51.2 \\
\hline COD & 48.60 & 9.910 & 25.610 & 79.6 & 47.3 \\
\hline $\mathrm{N}-\mathrm{NO}_{3}^{-}$ & 0.33 & 0.087 & 0.209 & 73.5 & 36.8 \\
\hline $\mathrm{P}-\mathrm{PO}_{4}{ }^{3-}$ & 0.39 & 0.085 & 0.310 & 78.2 & 20.5 \\
\hline SS & 15.00 & 4.890 & 10.990 & 67.4 & 26.7 \\
\hline
\end{tabular}

Note: M0: Water sample at first day (An Duong Lake water taken for experiment); M1: Water sample taken after fifteen days of experiment with hyacinth; M2: Water sample for blank (without hyacinth)

Table 4. Result of treatment of water containing storks' feces by horizontal filtration combined with EM

\begin{tabular}{lllrcc}
\hline & \multicolumn{5}{c}{ Results } \\
& \multicolumn{1}{c}{--------------------- } & Treatment \\
No. & Paramater & Unit & Sample 1 & Sample 1 & efficiency (\%) \\
\hline 1 & $\mathrm{SS}$ & $\mathrm{mg} / \mathrm{L}$ & 215.00 & 62.00 & 71.16 \\
2 & $\mathrm{BOD}_{5}$ & $\mathrm{mg} / \mathrm{L}$ & 54.00 & 17.20 & 68.14 \\
3 & $\mathrm{COD}$ & $\mathrm{mg} / \mathrm{L}$ & 63.00 & 27.00 & 57.14 \\
4 & $\mathrm{pH}$ & & 6.55 & 6.58 & -0.00 \\
5 & $\mathrm{P}_{\text {total }}$ & $\mathrm{mg} / \mathrm{L}$ & 8.01 & 4.30 & 46.31 \\
6 & $\mathrm{~N}_{\text {total }}$ & $\mathrm{mg} / \mathrm{L}$ & 14.20 & 7.12 & 49.85 \\
7 & $\mathrm{~N}^{+} \mathrm{NH}_{4}{ }^{+}$ & $\mathrm{mg} / \mathrm{L}$ & 5.60 & 1.76 & 68.57 \\
8 & $\mathrm{~N}^{-N_{3}}{ }^{-}$ & $\mathrm{mg} / \mathrm{L}$ & 23.10 & 5.84 & 74.71 \\
\hline
\end{tabular}

\subsubsection{Wet season (From May to October)}

In comparison with Vietnam National Technical Regulation 08:2008/BTNMT, in wet season, concentration of SS of water samples N4, N5 is lower than B1 class and BOD of water samples N8, N12 is lower than permissible level (B1 class). Concentration of $\mathrm{SS}$ and BOD of the others is higher than class B1.

Concentration of COD of samples N8, N12 is lower than $\mathrm{B} 1$ class, concentration of COD of 10 other samples is higher than $\mathrm{B} 1$ class.

Concentration of $\mathrm{N}^{-\mathrm{NH}_{4}}{ }^{+}$and $\mathrm{N}-\mathrm{NO}_{3}{ }^{-}$of all samples is lower than Permissible level (A2 and B1 class).

Concentration of SS of samples: N6, N7, N8 which are located near shoreline or drainage gate is higher than that of other samples.

Concentration of $\mathrm{BOD}_{5}$, COD of samples: N1, N6 and $\mathrm{N} 9$ which are located near shoreline and households on lakeshore is higher than that of other samples.

\subsubsection{Comparison}

In dry season, water of An Duong Lake is more contaminated than in wet season due to small amount of water (rainfall and run-off) for diluting and significantly decreased water level in the lake. Meanwhile, the pollutant loading of storks' feces, domestic and livestock waste water is almost constant.

Lake and island shore water is much more polluted than central water because of the tiny differences in water-in and water-out in term of its amount and velocity. This prevents the contaminants from moving into the central part of the lake.

\subsection{Suggested Comprehensive Measures for Improving An Duong Lake Water Quality and Contribution to Stork Islands Conservation}

\subsubsection{Water Hyacinth (Eichhornia crassipes) Growing (dropping) for Water Pollutant Mitigation}

The field survey and results of interviewing people living around An Duong Lake demonstrate that hyacinths are floating plants which are used for feeding domestic animals (cattle, pigs, chickens...) by farmers. In addition, the wind can easily wear out the water hyacinth cover and push it to move. It means hyacinth has a very good adaptation in the water environment and has capacity to remove organic matter containing in water (Loan and Huy, 2006; Thao, 1999; Yem et al., 2010). Therefore water hyacinth has been selected as a pollutant-remover for the lake water. The result of field tests and experiments shows that hyacinth can remove $73.5 \% \mathrm{NO}_{3}{ }^{-}, 78.2 \% \mathrm{PO}_{4}{ }^{3-}, 85.1 \% \mathrm{BOD}_{5}, 79.6 \% \mathrm{COD}$ and $67,4 \%$ SS. Hyacinth's long and thick roots have supported to absorb a large amount of nutrient substances as well as other pollutants in water (Loan and Huy, 2006; Loan and Quy, 2010). On the other hand, this root is also as a "substrate" helping the microorganism's adhesion, growth and development and rapidly reduces the concentration of organic matter in the water (Yem et al., 2010). After 15 days of experiments, water hyacinths are found out to grow very well (hyacinth cover increasing) (Fig. 4).

\subsubsection{Reed (Phragmites Communis) Growing for Water Pollutant Mitigation}

Reed (Phragmites communis): Reed can grow everywhere especially in hot and humid climate (tropical climate), the optimal environmental temperature for reed growth is $12-30^{\circ} \mathrm{C}$. Reed can grow in water at the depth of 30-150 $\mathrm{cm}$ and with the $\mathrm{pH}=2-8$ (Loan and Huy, 2006; Thao, 1999). Reed's root grows very quickly and adheres to the soil. Around the reed's root in the soil, there are many bacteria like in the aeration tank. 

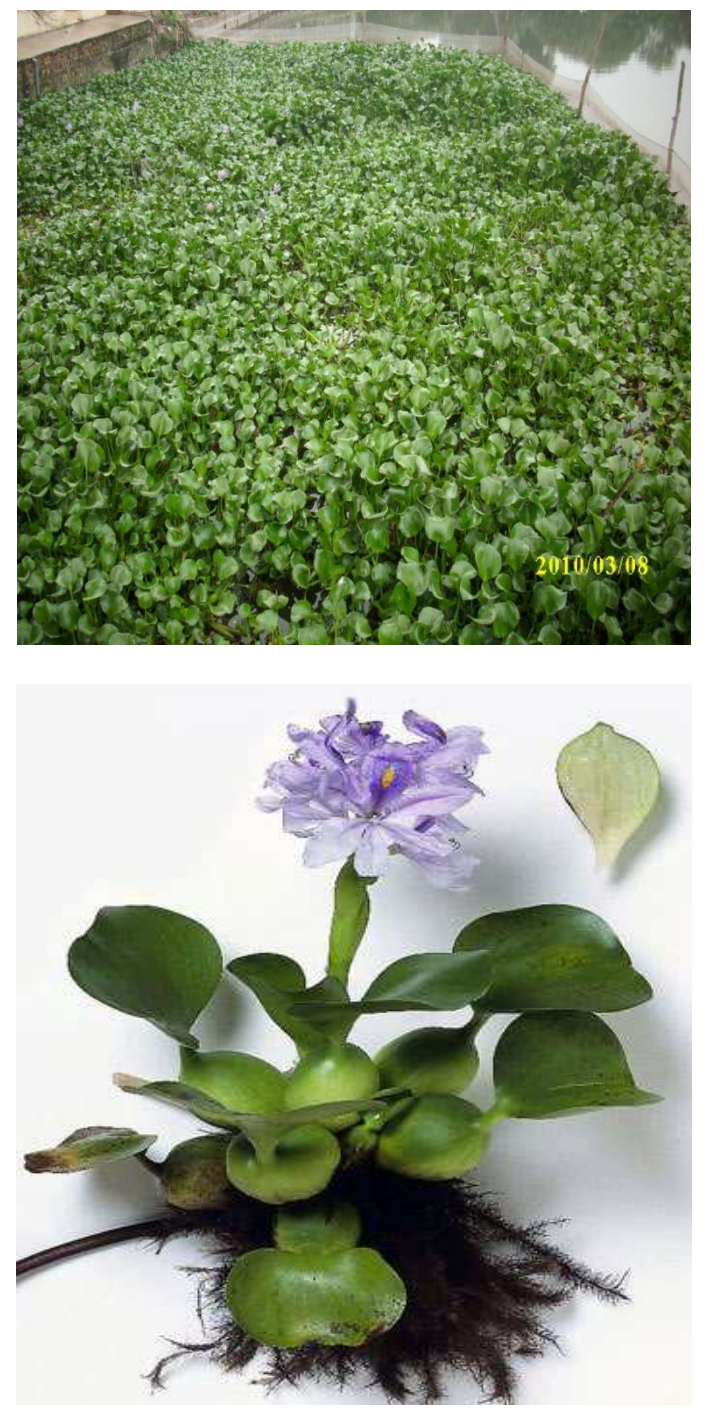

Fig. 4. Hyacinth in a Duong Lake

Therefore reed fields could be used as a biological treatment unit for domestic and industrial waste water. In the $60 \mathrm{~s}$ of the $20^{\text {th }}$ century and recent years, Kathe Seidel and many others have applied this method for waste water treatment with the efficiency of $80-90 \%$ for $\mathrm{NH}_{4}^{+}, \mathrm{NO}_{3}^{-}$, $\mathrm{PO}_{4}{ }^{3-}, \mathrm{BOD}_{5}, \mathrm{COD}$, Coliform (Yem et al., 2010).

Base on previous studies (Loan and Huy, 2006; Loan and Quy; 2010, Phuong et al., 2011; Thanh, 2010, Vymazal and Kropfelova, 2008; Minh and Tuan, 2005) and An Duong Lake field survey, reed planting (15 reeds $/ \mathrm{m}^{2}$ ) along some important sections of An Duong lakeshore and in the canal connecting An Duong Lake with Trieu Duong Lake is highly recommended (Fig. 5).
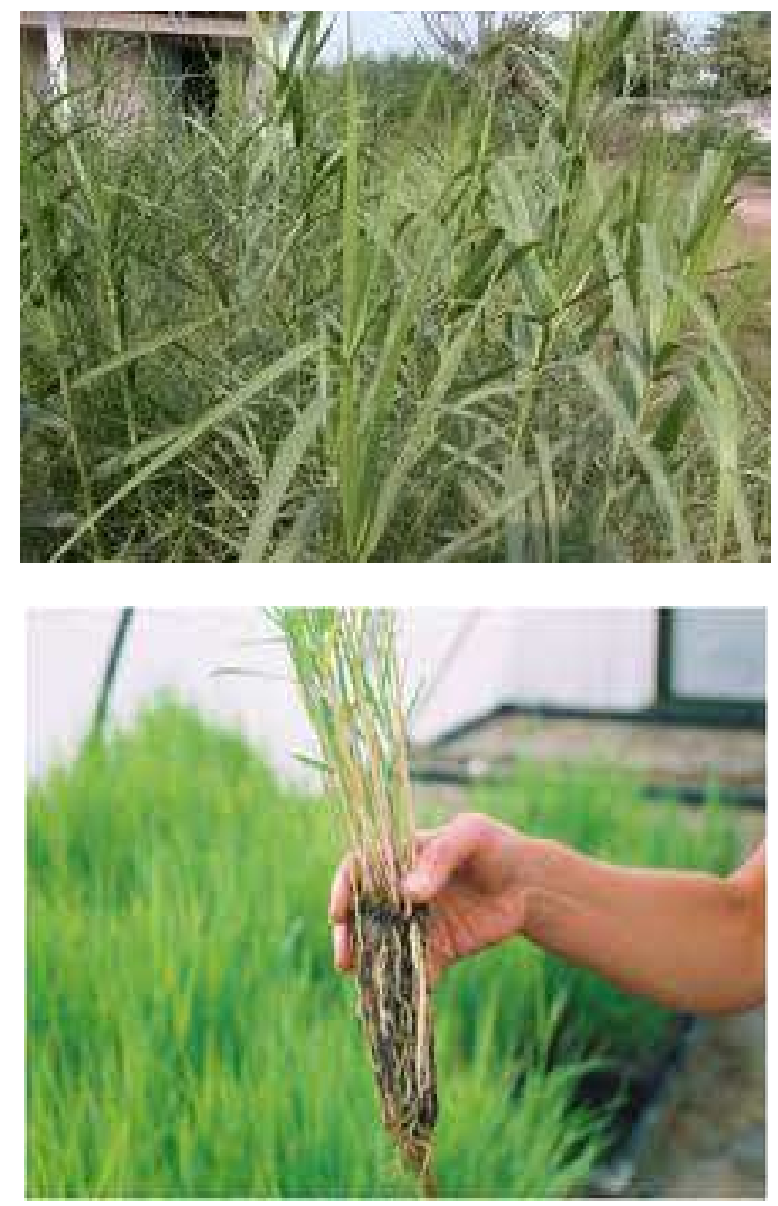

Fig. 5. Reed plants (Phragmites communis)

\subsubsection{Septic Tank Toilet for Treatment Domestic Waste Water}

At present, that An Duong lakeside households have no septic tank toilet and their domestic waste water without any treatment are discharged directly into the lake contributes to water pollution of An Duong Lake (Anh, 2008; Yem et al., 2009; Yem, 2012). It is essential to set up domestic waste water treatment facilities for households in the village. 3-Compartments latrine is recommended for each household.

\subsubsection{Treatment of Livestock Wastes}

Currently, about 50 An Duong lakeside households have pig farming and its waste water and manures are directly discharged into the lake (Anh, 2008; Yem, 2012). Two measures for livestock waste treatment are suggested: 
- Household scale biogas production

- Septic tank for collection and treatment of livestock waste water

\subsubsection{Filtration in Combination with EM for Mitigating Pollutant in Run-Off}

Trench around stork islands should be constructed. The trench is filled gravels and sands and it is considered as a horizontal filter. The experiment of filtration in combination with EM for reducing pollutant in run-off from islands was conducted.

EM technology was invented by Dr. Higa of Ruykyus University, Okinawa, Japan and applied in practice in the early 1980 (CDVJT, 2008).

EM products are currently used in many fields, especially for environmental pollution mitigation. EM can be used for livestock waste water treatment and clean-water of shrimp pond, EM can also be used for solid waste disposal and treatment of lake water in general (MONRE, 2005; Pham, 1998).

By this reasons, EM is used in this study to reduce storks' and cauldrons' feces in run-off by gravels and sands filtration in combination with EM.

In the experimental process (Fig. 2), dilution of EM and Molasses by percentage is as follow:

- $\quad$ EM 5\%

- Molasses (or brown sugar) 5\%

- Fresh water $90 \%$

Use 0.1 liters of EM added to the compartment No. 2 (compartment with gravels and sands) (the dose recommended by the manufacturer is $1 / 1000$ compared to the amount of waste water), after about 4-5 days, water is taken from compartment No. 3 for chemical analysis in laboratory.

The experimental results show that the filtration system using sand, gravel in combination with EM has reduced a large portion of storks' and cauldrons' feces in run-off from islands flowing into the lake. The treatment efficiency (\% removed) of this system is described well by the following statistics: SS (71.16\%), BOD5 (68.14\%), COD (57.14\%), $\mathrm{P}_{\text {total }}$ and $\mathrm{N}_{\text {total }}\left(46.31 \%\right.$ and $49.85 \%$ respectively), $\mathrm{N}^{-\mathrm{NH}_{4}{ }^{+} \text {and }}$ $\mathrm{N}-\mathrm{NO}_{3}{ }^{-}(68.57 \%$ and $74.71 \%$ respectively). Waste water treatment system using EM should be very effective if EM is supplemented in the earlier stages. This may promote and enhance the activities of microorganisms. Use of EM is also a good method for reducing odor from wastes.

\subsubsection{Fish Farming}

The nutrients nitrogen and phosphorus in water will promote growth and development of phytoplankton species (Crites, 1998; IWA, 2011; Thao, 1999). Along with the nutrients, organic material of plant species is also considered as an abundant food source for fish. Thus, fish with a certain scale of its population will help clean water and balance the ecosystem of the lake. In many lakes polluted by organic medium such as West Lake, Hoan Kiem Lake, fish farming method is regarded asthe simplest measure that helps improving water quality while maintaining economic efficiency and diversifying tourism activities.

\subsubsection{Pollution Sources Control and a Duong Lake water Monitoring}

Periodical control should be implemented for An Duong Lake water pollution sources such as: source of storks' and cauldrons' feces, domestic activities, livestock and tourism activities. Pollution sources control focus on:

- Making list of pollution source (pollution source description)

- Treatment facilities

- Wastes discharge facilities and drainage

- Activities of tourists and visitors

- People's compliance with environmental regulations

Monitoring for An Duong Lake water quality should be implemented as follow:

- Monitoring site selection: 12 proposed site as showed on Fig. 1

- Monitoring parameters: toC, $\mathrm{pH}$, turbidity, $\mathrm{SS}, \mathrm{DO}$, BOD, COD, N-NH ${ }_{4}^{+},{\mathrm{N}-\mathrm{NO}_{3}}^{-}, \mathrm{P}_{\text {total }}, \mathrm{N}_{\text {total }}$, heavy metal, Coliform

- Monitoring frequency: twice a year (dry and wet season)

\section{CONCLUSION}

An Duong Lake is being regarded as an important part of the habitat of storks and cauldrons, fish farming and ecotourism, but the quality of water has been degraded by increasing storks' and cauldrons' feces, domestic, livestock wastes and run-off. To conserve storks and cauldrons and develop ecotourism, comprehensive measures for improving water quality should be implemented. 


\section{ACKNOWLEDGEMENT}

The researchers of this study are grateful to the Vietnam National University, Hanoi (VNU) for its funding for the Project: "Research on Environmental and Ecosystem characteristics of stork colony for Reserve and Eco-tour development (take Ngoc Nhi-Ba Vi-Ha Noi and Chi Lang Nam-Hai Duong stork colony for example)", Code: QGTD 10-07. Many thanks are given to Prof. Mai Trong Nhuan (Director of VNU), Prof. Nguyen Cao Huan (Science and Technology BoardVNU), Assoc. Prof. Tran Thi Hong (Science and Technology Office of Hanoi University of ScienceHUS), Assoc. Prof. Luu Duc Hai, Assoc. Prof. Nguyen Thi Ha (Faculty of Environmental Sciences-HUS) for their valuable comments on the content of the research.

\section{REFERENCES}

Anh, B.D., 2008. Research on soil and water quality of stork island, chi lang nam commune, thanh mien district, Hai Duong province. MSc, Thesis, Hanoi University of Science (HUS).

CDVJT, 2008. Center for Development of VietnamJapan Technology-Introduction to Effective Microorganisms EM. 1st Edn., Hanoi.

Crites, R.W., 1998. Small and Decentralized Wastewater Management Systems. 1st Edn., McGraw Hill, Boston, ISBN-10: 0072890878, pp: 1084.

IWA, 2011. Microbes in wastewater and waste treatment, bioremediation and energy production. International Water Association, Goa, India.

JSWA, 1997. Guideline and manual for planning and design in sewage system.

Loan, N.T. and P.T. Huy, 2006. Assessment of waste water treatment ability of some aquatic plants in constructed wetland system. VNU J. Sci., Natural Sci. Technol., 22: 62-67.

Loan, N.T. and T.V. Quy, 2010. Studying use of constructed wetland system to treat To Lich River's water for agriculture production purposes. VNU J. Sci., Natur. Sci. Technol., 26: 798-802.

Minh, V.V. and V.C. Tuan, 2005. Heavy metals in soil treatment by plant. J. Sci. Technol., 4: 60-62.

MONRE, 2005. Ministry of Natural Resources and Environment-Using Effective Microorganism (EM) for Mitigating Rural Environmental Pollution. 1st Edn., Hanoi.
Pham, L.D., 1998. Microbiological treatment technology. 1st Edn., Agriculture Publishing House, Hanoi.

Phuong, N.M., N.T. Loan and N.T.N. Anh, 2011. Initial research on wetland plants and microbial communities in domestic waste water treatment. VNU J. Sci. Natur. Sci. Technol., 27: 203-208.

Thanh, T.T., 2010. The research's result for Nitrogen treatment of the domestic waste water by using the curves plastic in the biological underwaterfiltration method. VNU J. Sci. Natur. Sci. Technol., 26: 853-858.

Thao, L.H., 1999. Study on biological treatment processes and water pollution in some lakes in Hanoi. Doctoral Thesis, Hanoi University of Science (HUS).

Vymazal, J. and L. Kropfelova, 2008. Waste Water Treatment in Constructed Wetlands with Horizontal Sub-Surface Flow. 1st Edn., Dordrecht, Springer, ISBN-10: 140208580X, pp: 566.

Yem, T., N.X. Hai, N.H. Huan and N.H. Duc, 2009. Study on water pollution of an duong lake, chi lang nam commune, thanh mien district, hai duong province. J. Natur. Resour. Environ. Ministry Natur. Resour. Environ., 11: 36-39.

Yem, T., N.T. Loan, H.M. Lam and T.V. Viet, 2010. Assessing the ability to treat nitrogen compounds in the water of To Lich River of a constructed wetland with different aquatic plant species. VNU J. Sci. Natur. Sci. Technol., 26: 804-809.

Yem, T., N.X. Hai, D.V. Vinh and T.T. Phuong, 2012. Study on improving quality of An Duong lake by water hyacinth and horizontal filtration trenche. VNU J. of Science, Natural Science and Technology, 28: 145-152.

Yem, T., 2012. Research on enviromental and ecosystem characteristics of stork colony for reserve and ecotour development (Take Ngoc Nhi-Ba Vi-Hanoi and Chi Lang Nam-Hai Duong Stock Colony for example). VNU special Project, Code QGTD 10-07. 